\title{
Does progesterone inhibit bacteria-stimulated interleukin-8 production by lower genital tract epithelial cells?
}

\author{
Morgan R. Peltier ${ }^{1-3, *}$, Yana Berlin ${ }^{1,4}$, Siew C. \\ Tee $^{4}$ and John C. Smulian ${ }^{5}$ \\ ${ }^{1}$ Perinatal Research Laboratory, Applied Bench Core, \\ Winthrop University Hospital, Mineola, NY, USA \\ 2 Division of Maternal-Fetal Medicine, Department of \\ Obstetrics and Gynecology, Winthrop University \\ Hospital, Mineola, NY, USA \\ ${ }^{3}$ Division of Neonatology, Department of Pediatrics, \\ Winthrop University Hospital, Mineola, NY, USA \\ ${ }^{4}$ Division of Maternal-Fetal Medicine, Department of \\ Obstetrics, Gynecology and Reproductive Sciences, \\ UMDNJ-Robert Wood Johnson Medical School, \\ New Brunswick, NJ, USA \\ ${ }^{5}$ Division of Maternal-Fetal Medicine, Department of \\ Obstetrics and Gynecology, Lehigh Valley Hospital, \\ Allentown, PA, USA
}

\begin{abstract} associated with preterm birth. reduction of a tetrazolium salt.

\footnotetext{
${ }^{*}$ Corresponding author:

Morgan R. Peltier, PhD

Perinatal Research Laboratory

Applied Bench Core

Winthrop University Hospital

Mineola, NY 11501

USA

Tel.: +1 (516) 6632035

Fax: +1 (516) 663-8871

E-mail: mpeltier@winthrop.org
}

Objective: Progesterone $\left(\mathrm{P}_{4}\right)$ has been clinically shown to prevent the recurrence of preterm birth. The mechanism(s) of action is unclear, but may involve modulation of the immunologic inflammatory response of the lower genital tract. We evaluated the effects of $\mathrm{P}_{4}$ on interleukin-8 (IL-8) production by vaginal and cervical epithelial cells stimulated with bacterial species that are commonly

Methods: Vaginal and endocervical epithelial cells were incubated with up to $10,000 \mathrm{ng} / \mathrm{mL} \mathrm{P}_{4}$ overnight and stimulated with heat-killed Escherichia coli, Gardnerella vaginalis, or Ureaplasma urealyticum. Concentrations of IL-8 in conditioned medium were quantified by ELISA and viability of the cell cultures was measured by the

Results: E. coli, G. vaginalis and $U$. urealyticum-stimulated IL-8 production for both cell lines. $\mathrm{P}_{4}$ inhibited basal and bacteria-stimulated IL-8 production for vaginal epithelial cells but enhanced IL-8 production by endocervi- cal cells. $\mathrm{P}_{4}$ reduced the number of viable cells for both cell lines.

Conclusions: $\mathrm{P}_{4}$ inhibits IL-8 production by vaginal epithelial cells stimulated with pathogens associated with preterm birth, possibly by reducing the number of viable cells or by inhibiting their proliferation. Although $\mathrm{P}_{4}$ also reduces proliferation of endocervical cells it also increases their production of IL-8.

Keywords: Infection; innate immunity; preterm birth; progesterone; vaginal immunity.

\section{Introduction}

Supplemental progesterone or progestin $\left(\mathrm{P}_{4}\right)$ has been shown to prevent recurrent preterm birth in several clinical trials $[6,19,22]$, however, the mechanism by which $\mathrm{P}_{4}$ functions to prevent preterm birth remains unclear. Two recent studies have suggested that supplemental $P_{4}$ via vaginal suppositories prevents preterm birth in women with a short cervix [7, 13] and may also improve neonatal outcomes by reducing both admissions and lengths of stay at the neonatal intensive care unit [7]. In fact, $\mathrm{P}_{4}$ had no significant effect on preterm birth in women with cervical lengths $>28 \mathrm{~mm}$. These studies suggest that the lower genital tract may be a target tissue for this hormone.

Many spontaneous preterm births are thought to be the end result of infections that ascend from the vagina through the cervix and become established in the upper genital tract. Bacterial products such as lipopolysaccharide (LPS) increase interleukin (IL)-8 production by cervical cells [29]. Aberrantly high concentrations of IL-8 in cervical-vaginal fluids have previously been correlated with preterm birth and chorioamnionitis [17] and both IL8 and LPS have been shown to induce cervical ripening in animal models $[5,8,9]$. Premature cervical ripening could potentially permit bacteria to ascend into the upper genital tract where they can stimulate a preterm labor response. We therefore hypothesized that $\mathrm{P}_{4}$ may prevent preterm birth by inhibiting bacteria-stimulated IL-8 production by cells of the lower genital tract. To test the biologic principle underlying this hypothesis, we used an in vitro model to test whether $\mathrm{P}_{4}$ can alter IL-8 production by vaginal and endocervical cells exposed to bacterial pathogens commonly associated with infection-mediated preterm birth. 


\section{Materials and methods}

\section{Cell lines and bacterial cultures}

Vaginal (VK2E6E7) and endocervical epithelial cells (ENDE6E7) were purchased from ATCC (Manassas, VA) for utilization in this experiment. These cell lines were produced from primary cultures isolated from non-pregnant subjects and immortalized by in vitro infection with human papilloma virus 16 and retain many characteristics of primary cells in terms of keratin expression [10]. Therefore, the responses of these cells are probably more physiological than other cell lines. Cells were propagated in keratinocyte serum-free (KSM) medium and split at 70-90\% confluence by trypsinization. Stock reference cultures of Escherichia coli, Gardnerella vaginalis, Ureaplasma urealyticum (U. urealyticum serotype 1-now reclassified as $U$. parvum) were also purchased from ATCC. E. coli and G. vaginalis were cultivated as directed. $U$. urealyticum was cultivated in beef heart infusion $+20 \%$ horse serum $+10 \%$ Yeast extract dialysate $+1 \mathrm{~g} / \mathrm{L}$ urea $+20 \mathrm{mg} / \mathrm{L}$ phenol red. Organisms were harvested by centrifugation at 10,000 $g$ and re-suspended in KSFM or RPMI 1640. The number of colony forming $\mathrm{U} / \mathrm{mL}$ was then determined for $E$. coli or $G$. vaginalis by plating serial dilutions on the appropriate agar. Re-suspended cultures of $U$. urealyticum were quantified by measuring the color changing units (CCU), defined as the lowest 10-fold dilution that causes a color change (indicating growth) in the broth above. Bacteria were heat-killed by heating at $80^{\circ} \mathrm{C}$ for $1 \mathrm{~h}$ and aliquots of the heat-killed bacteria were stored at $-70^{\circ} \mathrm{C}$ until use. This is a standard method of preparing bacteria for in vitro experiments to test cellular immune responses to bacterial components (live bacteria divide rapidly and would quickly overgrow the mammalian cells in culture).

\section{Cell cultures}

Freshly split cells (diluted 1:4 after trypsinization) were plated on 96-well plates in $160 \mu \mathrm{L}$ medium and permitted to adhere overnight in a humidified incubator at $37^{\circ} \mathrm{C}$ in a $5 \% \mathrm{CO}_{2}(\mathrm{v} / \mathrm{v})$ atmosphere. $\mathrm{P}_{4}$ treatments were then added to final concentration $(0-10,000 \mathrm{ng} / \mathrm{mL})$ in a volume of $20 \mu \mathrm{L} \mathrm{KSM}+10 \%$ fetal bovine serum $+1 \%$ Dimethyl sulfoxide and cultures were incubated overnight as described above. Cells were then stimulated by adding heat-killed bacteria or an equivalent volume $(20 \mu \mathrm{L})$ of vehicle and returned to the incubator for a final overnight incubation. A harvest of $100 \mu \mathrm{L}$ of the conditioned medium was stored at $-70^{\circ} \mathrm{C}$ until assay for IL-8 by ELISA using reagents purchased from $\mathrm{R}$ and $\mathrm{D}$ systems (Minneapolis, MN). Potential effects of $\mathrm{P}_{4}$ on number of viable cells was evaluated using the MTT assay as previously described [25]. Briefly, $20 \mu \mathrm{L}$ tetrazolium salt $(5 \mathrm{mg} / \mathrm{mL})$ was incubated for $2 \mathrm{~h}$ at $37^{\circ} \mathrm{C}$. Formosan crystals formed by live cells were then dissolved by adding $100 \mu \mathrm{L} 10 \%$ SDS $+0.01 \mathrm{M} \mathrm{HCl}$ to each well and incubating the plate at $37^{\circ} \mathrm{C}$ overnight. Optical density at 570 and $690 \mathrm{~nm}$ was quantified on a microplate spectrophotometer and data are expressed as $\mathrm{OD}_{570-690}$, which is directly proportional to the relative number of live cells.

\section{Statistical analyses}

Data were analyzed using the general linear models procedure of SAS (SAS Institute, Cary, NC) for a randomized block design. Effects due to experiment were considered random and all others fixed. Results are reported as least-square means with accompanying asymptotic standard errors. Data from each experiment were evaluated for deviations from the assumptions of least-squares techniques (normality, equality, and independence of errors). When violations of the assumptions of ANOVA were detected, data were transformed using the Box-Cox algorithm [23]. Analyses from the transformed data were used for hypothesis testing ( $\mathrm{P}$-values). All data presented are from the untransformed dataset for clarity of presentation. IL-8 concentrations were not adjusted for confounding by viability of the cell cultures due to the possibility that any observed changes in IL8 production may be caused by changes in the number of viable cells and would, therefore, violate the assumptions of analysis of covariance.

\section{Results}

\section{Vaginal epithelial cells}

IL-8 production by vaginal epithelial cells was significantly increased upon stimulation with $10^{8} \mathrm{CFU} / \mathrm{mL}$ E. coli (1418.47 \pm 454.03 vs. $6031.53 \pm 454.03 \mathrm{pg} / \mathrm{mL}$; control vs. stimulated cells; $\mathrm{P}=0.0116), 2 \times 10^{6} \mathrm{CFU}$ G. vaginalis (1324.06 \pm 149.80 vs. $2991.49 \pm 149.80$ $\mathrm{pg} / \mathrm{mL} ; \mathrm{P}=0.0024)$ or $11 \mathrm{CCU} U$. urealyticum (2270.02 \pm 429.25 vs. $14028.89 \pm 429.25 \mathrm{pg} / \mathrm{mL} ; P=0.0036) . P_{4}$ significantly decreased IL-8 production by cultures stimulated with these pathogens as well as unstimulated cells but only at the highest concentration $(10,000 \mathrm{ng} / \mathrm{mL})$ tested (Figure 1). At this concentration, $\mathrm{P}_{4}$ also significantly reduced the number of viable cells for unstimulated cultures $(\mathrm{P}<0.001)$ as well as those treated with $E$. coli $(P<0.001)$, G. vaginalis $(P<0.001)$ or $U$. urealyticum $(\mathrm{P}<0.001)$.

\section{Endocervical cells}

IL-8 production by endocervical cells was slightly enhanced by stimulation with $E$. coli $(2129.34 \pm 88.10$ vs. $2946.65 \pm 88.10 \mathrm{pg} / \mathrm{mL}$; control vs. treated; $\mathrm{P}=0.0286)$, G. vaginalis $(2296.85 \pm 120.74$ vs. $5378.50 \pm 120.74$ $\mathrm{pg} / \mathrm{mL} ; \mathrm{P}=0.0154)$, or $U$. urealyticum (1920.23 \pm 166.43 vs. $3288.87 \pm 166.43 \mathrm{pg} / \mathrm{mL} ; P=0.0668)$. Both basal and bacteria-stimulated IL-8 production was enhanced by $\mathrm{P}_{4}$ in a dose-dependent manner, however, results were only significant for cultures treated with very high doses of 1000 and $10,000 \mathrm{pg} / \mathrm{mL}_{4}$ (Figure 2). As with vaginal epithelial cells, the number of viable cells was reduced by $1000-10,000 \mathrm{pg} / \mathrm{mL} \mathrm{P}_{4}$ (Figure 2).

\section{Discussion}

We found that E. coli, G. vaginalis and $U$. urealyticum increase the production of IL-8 by both vaginal and cervical epithelial cells. This is consistent with previous studies which reported that Neisseria gonorrhoeae induce the 

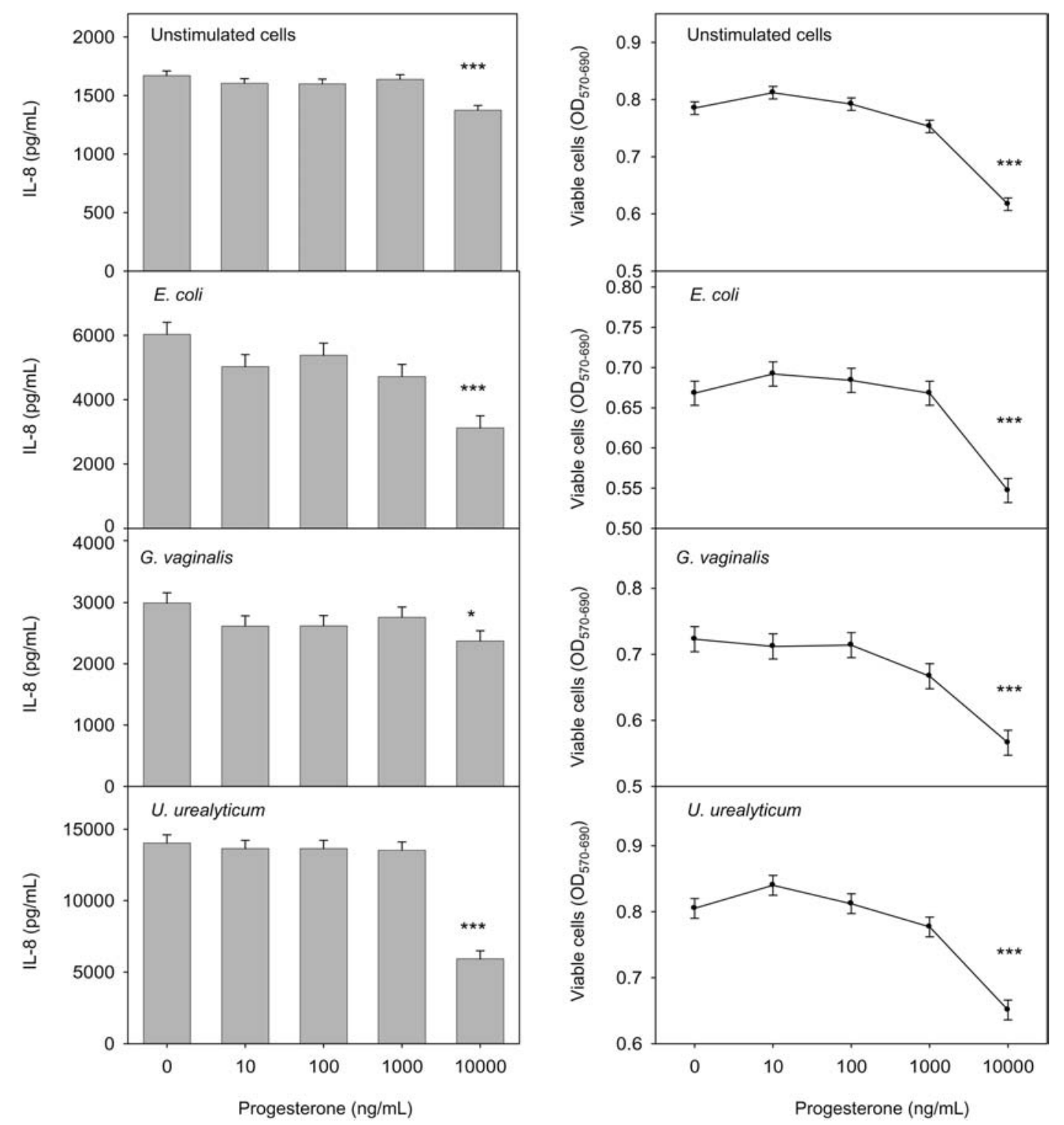

Figure $1 \quad \mathrm{P}_{4}$ decreases bacteria-stimulated IL-8 production by vaginal epithelial cells. Vaginal epithelial cells were treated with $0-10,000 \mathrm{ng} / \mathrm{mL} \mathrm{P}_{4}$ overnight and then stimulated with $10^{8} \mathrm{CFU} / \mathrm{mL}$ heat-killed $E$. coli for, $2 \times 10^{6} \mathrm{CFU} / \mathrm{mL}$ G. vaginalis or $11 \mathrm{CCU}$ of $U$. urealyticum or an equivalent volume of sterile medium (unstimulated cells) in separate experiments. Shown are least-squares means \pm SEM for IL-8 production (left panels) and relative number of viable cells as determined by the MTT assay (right panels). Points marked with an asterisk(s) are significantly different from $0 \mathrm{ng} / \mathrm{mL} P_{4}$ for that bacterial treatment $\left({ }^{\star} P<0.05\right.$; ${ }^{\star \star} P<0.01$; $\left.{ }^{* * *} \mathrm{P}<0.0001\right)$.

production of proinflammatory chemokines by these cell lines [12]. Clinical studies have also shown an association with increased IL-8 levels in vaginal lavage of women with genital mycoplasmas compared with normal flora [28]. IL-8 levels in vaginal fluid are also positively correlated with concentrations of $\lg A$ to $G$. vaginalis hemolysin [2] which is consistent with our results.

In general, we found that $\mathrm{P}_{4}$ significantly decreased bacteria-stimulated IL-8 production by vaginal epithelial cells for all pathogens studied as well as for cultures not treated with bacteria. This immunosuppressive effect is consistent with the observation that progesterone enhances the establishment of infections with Mycoplasma pulmonis [15], M. pneumoniae [14, 15], M. genitalium [15], Chlamydia [20] and herpes simplex virus [16] in animal models. Part of the mechanism for $\mathrm{P}_{4}$-immunomodulation of bacteria-stimulated IL-8 production may involve effects on viability or proliferation of the vaginal epithelial cells. High concentrations of $\mathrm{P}_{4}$ consistently lowered the number of viable vaginal epithelial cells regardless of whether or not pathogens were present. This is consistent with previous studies that reported 

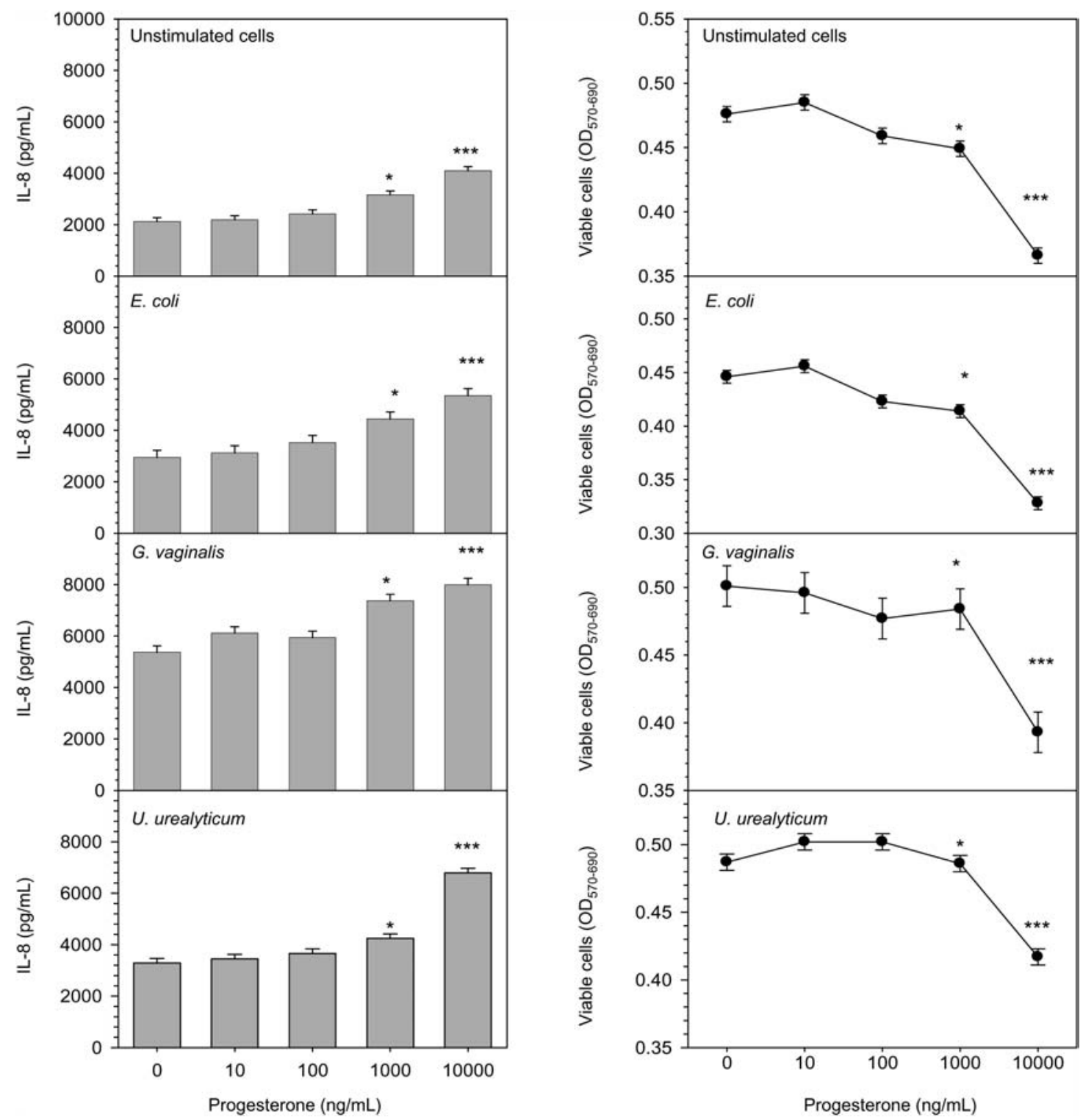

Figure 2 Effect of $P_{4}$ on bacteria-stimulated IL-8 production by endocervical epithelial cells. Cells were incubated with 0-10,000 $\mathrm{ng} / \mathrm{mL}_{4}$ overnight and then left unstimulated or treated with heat-killed $E$. coli, G. vaginalis or $U$. urealyticum. Shown are results pooled for 3-9 separate experiments.

reductions of vaginal epithelium thickness in vivo by $\mathrm{P}_{4}$ [24].

Previous studies demonstrated that $\mathrm{P}_{4}$ can suppress IL-8 production in the rabbit cervix [18], therefore, we hypothesized that high concentrations of $\mathrm{P}_{4}$ may block bacteria-stimulated increases in IL-8 production that, in turn, may prevent premature cervical ripening and its consequences, including preterm birth. Contrary to our expectation, however, we found that $\mathrm{P}_{4}$ increases basal and bacteria-stimulated production of IL-8 by endocervical cells. These results differ from those of a previous report where $\mathrm{P}_{4}$ had no effect on basal or phorbol esterstimulated IL-8 production by cervical explants from non- pregnant women [1]. The difference between these results may be due to the concentrations of $\mathrm{P}_{4}$ used to treat the cultures. Barclay et al. used $1 \mu \mathrm{M} \mathrm{P} \mathrm{P}_{4}$ which is equivalent to $314.5 \mathrm{ng} / \mathrm{mL}$. We tested $\mathrm{P}_{4}$ at concentrations of up to $10,000 \mathrm{ng} / \mathrm{mL}$ which were supraphysiological because concentrations in the term placenta are only about $2000-3000 \mathrm{ng} / \mathrm{g}$ tissue [21]. It is likely however, that the concentration used in our in vitro study are still lower than what would be present in the lower genital tract after intravaginal placement of $90-200 \mathrm{mg} \mathrm{P}_{4}$ as was done in the two protocols demonstrating $\mathrm{P}_{4}$ 's effectiveness at preventing preterm birth in women with a short cervix $[7,13]$. 
Although we found that high levels of $\mathrm{P}_{4}$ enhance rather than inhibit IL-8 production in the cervix, recent evidence suggests that a small increase in IL-8 could be beneficial in preventing preterm birth. Asymptomatic women who later go on to develop intra-amniotic infection had lower levels of IL-8, IL-1 $\beta$ and IL- 6 in the cervix compared to women who did not [27]. It is proposed that the lower levels of cytokines resulted in hypo-responsiveness to bacteria and enabled infections to become more easily established in the cervix and to ascend into the upper genital tract [27]. A slight enhancement of IL8 production and perhaps other proinflammatory mediators by $\mathrm{P}_{4}$ in the cervix may help to clear infections before they become established in the cervix and trigger a much more robust IL-8 response that causes a massive host response that results in cervical ripening and preterm birth.

Our finding that $\mathrm{P}_{4}$ decreased the number of viable endocervical cells suggests that augmentation of IL-8 levels is not due to any proliferative effect of $P_{4}$ on the cells. Although fewer endocervical cells are present in $\mathrm{P}_{4}$-treated cultures, it is likely that they could still produce more IL-8 upon stimulation with bacteria if IL-8 production in each cell was increased enough to compensate for the $20 \%$ fewer live cells that are present. Although it is possible that high concentrations of $\mathrm{P}_{4}$ are toxic to cells, it is more likely that this hormone reduces their proliferation. A previous study reported that injection of medroxyprogesterone decreases DNA synthesis in the rabbit endocervix [3]. $\mathrm{P}_{4}$ may do this by lowering the expression of the epithelial growth factor receptor on endocervical cells [4]. A small amount $(0.1 \mathrm{ng} / \mathrm{mL})$ of epidermal growth factor in the medium is required for the cultivation of these cells [11] and $\mathrm{P}_{4}$-mediated reductions in the EGF receptor may inhibit the proliferation of these cells as well.

Although a number of other cytokines are increased during cervical ripening, we chose to focus on IL-8 for several reasons. First, our preliminary studies demonstrated that the cell lines responded most robustly to bacterial stimulation with this cytokine. Second, IL-8 is a chemoattractant and activator of neutrophils which are recruited to the cervix during ripening. IL-8 levels are positively correlated with granulocyte elastase levels in the cervix [26]. Third, placement of IL-8 into the cervix causes ripening in animal models [5, 9]. Although other proinflammatory cytokines such as TNF- $\alpha$ and IL-1 $\beta$ are increased in the cervix during cervical ripening, these cytokines also induce the production of IL-8 by endocervical cells [9]. Therefore, their biological activity for promoting cervical ripening may be mediated, at least in part, through IL-8 production. Genetic knock-out mice for many proinflammatory cytokines such as IL-1 $\beta$, TNF$\alpha$, and MCP- 1 are available and we are unaware of any defects in cervical ripening in such animals. Therefore, we chose to study IL-8 as a model cytokine for the host- immune response, and to test variety of species of bacteria containing different virulence factors rather than a variety of cytokines and chemokines that would be highly correlated with one another.

Our results are also limited by several factors that are inherent to in vitro experiments with transformed cell lines. For example, we are unable to account for the impact that other maternal or fetal hormones or cell types in the lower genital tract may have had on the ability for $\mathrm{P}_{4}$ to modulate IL-8 concentrations in the cervix or the vagina. We are also unable to determine what exposure to $\mathrm{P}_{4}$ over the course of many weeks may have on the responsiveness of cells to bacteria. Furthermore, immune responses to a live, growing culture of bacteria in vivo may be markedly different from those generated by stimulation of cells with heat-killed organisms. These limitations could partially be overcome by quantifying cervical levels of IL-8, and bacteria in clinical samples from women taking supplemental progesterone. It would be very difficult now, however, to get samples from a control group with similar reproductive histories since the use of this hormone for preventing preterm birth is now widespread. It would also be difficult to interpret how cervical cytokines respond to bacterial pathogens in women in vivo when the vaginal flora is complex and consists of many different species. In contrast, our study with transformed cells enabled to study many different treatments under carefully controlled conditions with human cells which would not be possible in a clinical setting.

\section{References}

[1] Barclay CG, Brennand JE, Kelly RW, Calder AA. Interleukin-8 production by the human cervix. Am J Obstet Gynecol. 1993;169:625-32.

[2] Cauci S, Guaschino S, Driussi S, De Santo D, Lanzafame P, Quadrifoglio F. Correlation of local interleukin-8 with immunoglobulin A against Gardnerella vaginalis hemolysin and with prolidase and sialidase levels in women with bacterial vaginosis. J Infect Dis. 2002;185:1614-20.

[3] Chilton BS, Gettys KL, Newman MG, McAllister CJ, Cowart KT. Differential responses of rabbit endocervix and uterus to medroxyprogesterone acetate. Steroids. 1985; 46:915-27.

[4] Chilton BS, Deeb EA, Dalley BK. Progesterone regulates epidermal growth factor receptor on mucous secreting cells in the rabbit endocervix. Endocrinology. 1991;129: 2094-100.

[5] Chwalisz K, Benson M, Scholz P, Daum J, Beier HM, Hegele-Hartung C. Cervical ripening with the cytokines interleukin 8, interleukin 1 beta and tumour necrosis factor alpha in guinea-pigs. Hum Reprod. 1994;9:2173-81.

[6] da Fonseca EB, Bittar RE, Carvalho MH, Zugaib M. Prophylactic administration of progesterone by vaginal suppository to reduce the incidence of spontaneous preterm birth in women at increased risk: a randomized placebocontrolled double-blind study. Am J Obstet Gynecol. 2003; 188:419-24. 
[7] DeFranco EA, O'Brien JM, Adair CD, Lewis DF, Hall DR, Fusey $\mathrm{S}$, et al. Vaginal progesterone is associated with a decrease in risk for early preterm birth and improved neonatal outcome in women with a short cervix: a secondary analysis from a randomized, double-blind, placebo-controlled trial. Ultrasound Obstet Gynecol. 2007;30:697-705.

[8] el Maradny E, Kanayama N, Halim A, Maehara K, Sumimoto $\mathrm{K}$, Terao T. Interleukin-8 induces cervical ripening in rabbits. Am J Obstet Gynecol. 1994;171:77-83.

[9] El Maradny E, Kanayama N, Halim A, Maehara K, Sumimoto K, Terao T. Biochemical changes in the cervical tissue of rabbit induced by interleukin-8, interleukin-1beta, dehydroepiandrosterone sulphate and prostaglandin E2: a comparative study. Hum Reprod. 1996;11:1099-104.

[10] Fichorova RN, Rheinwald JG, Andersen DJ. Generation of papillomavirus-immortalized cell lines from normal human ectocervical, endocervical and vaginal epithelium that maintain expression of tissue-specific differentiation proteins. Biol Reprod. 1997;57:847-55.

[11] Fichorova RN, Anderson DJ. Differential expression of immunobiological mediators by immortalized human cervical and vaginal epithelial cells. Biol Reprod. 1999;60: 508-14.

[12] Fichorova RN, Desai PJ, Gibson FC 3rd, Genco CA. Distinct proinflammatory host responses to Neisseria gonorrhoeae infection in immortalized human cervical and vaginal epithelial cells. Infect Immun. 2001;69:5840-8.

[13] Fonseca EB, Celik E, Parra M, Singh M, Nicolaides KH. Progesterone and the risk of preterm birth among women with a short cervix. N Engl J Med. 2007;357:462-9.

[14] Furr P, Taylor-Robinson D. Colonization of the respiratory and genital tracts of female mice with Mycoplasma pneumoniae and protection afforded to the genital tract by prior respiratory colonization. Int J Exp Pathol. 1999;80:35-9.

[15] Furr PM, Taylor-Robinson D. Factors influencing the ability of different mycoplasmas to colonize the genital tract of hormone-treated female mice. Int J Exp Pathol. 1993;74: 97-101.

[16] Gillgrass AE, Ashkar AA, Rosenthal KL, Kaushic C. Prolonged exposure to progesterone prevents induction of protective mucosal responses following intravaginal immunization with attenuated herpes simplex virus type 2. J Virol. 2003;77:9845-51.

[17] Holst RM, Mattsby-Baltzer I, Wennerholm UB, Hagberg H, Jacobsson B. Interleukin-6 and interleukin-8 in cervical fluid in a population of Swedish women in preterm labor: relationship to microbial invasion of the amniotic fluid, intra-amniotic inflammation, and preterm delivery. Acta Obstet Gynecol Scand. 2005;84:551-7.

[18] Ito A, Imada K, Sato T, Kubo T, Matsushima K, Mori Y.
Suppression of interleukin 8 production by progesterone in rabbit uterine cervix. Biochem J. 1994;301(Pt 1):183-6.

[19] Johnson JW, Austin KL, Jones GS, Davis GH, King TM. Efficacy of 17alpha-hydroxyprogesterone caproate in the prevention of premature labor. N Engl J Med. 1975;293: 675-80.

[20] Kaushic C, Zhou F, Murdin AD, Wira CR. Effects of estradiol and progesterone on susceptibility and early immune responses to Chlamydia trachomatis infection in the female reproductive tract. Infect Immun. 2000;68:4207-16.

[21] Lahav M, Sofer N, Brandes JM, Paldi E, Barzilai D. Placental concentrations of progesterone, estradiol-17 beta, and cyclic AMP at delivery. Obstet Gynecol. 1980;56 616-20.

[22] Meis PJ, Klebanoff M, Thom E, Dombrowski MP, Sibai B, Moawad $\mathrm{AH}$, et al. Prevention of recurrent preterm delivery by 17 alpha-hydroxyprogesterone caproate. N Engl J Med. 2003;348:2379-85.

[23] Peltier MR, Wilcox CJ, Sharp DC. Technical note: Application of the Box-Cox data transformation to animal science experiments. J Anim Sci. 1998;76:847-9.

[24] Pessina MA, Hoyt RF, Goldstein I, Traish AM. Differential effects of estradiol, progesterone and testosterone on vaginal structural integrity. Endocrinology. 2006;147:61-9.

[25] Russell CA, Vindelov LL. Optimization and comparison of the MTT assay and the $3 \mathrm{H}-\mathrm{TdR}$ assay for the detection of IL-2 in helper T cell precursor assays. J Immunol Methods. 1998;217:165-75.

[26] Sagawa T, Furuta I, Negishi H, Kishida T, Begum S, Fujimoto S. Cytokines concentrations in the cervical mucus of pregnant women. J Obstet Gynaecol Res. 1996;22:51722.

[27] Simhan HN, Caritis SN, Krohn MA, Martinez de Tejada B, Landers DV, Hillier SL. Decreased cervical proinflammatory cytokines permit subsequent upper genital tract infection during pregnancy. Am J Obstet Gynecol. 2003;189:560-7.

[28] Wasiela M, Brzezinska-Blaszczyk E, Krzeminski Z, Kalinka J. [Impact of Mycoplasma hominis and Ureaplasma ureaIyticum on the concentration of proinflammatory cytokines in vaginal fluid]. Med Dosw Mikrobiol. 2004;56:371-6.

[29] Watari M, Watari H, Fujimoto T, Yamada H, Nishihira J, Strauss JF, et al. Lipopolysaccharide induces interleukin-8 production by human cervical smooth muscle cells. J Soc Gynecol Investig. 2003;10:110-7.

The authors stated that there are no conflicts of interest regarding the publication of this article.

Received September 30, 2008. Revised November 24, 2008. Accepted November 27, 2008. Previously published online March 17, 2009 